\title{
JPCS
}

Peqguruang: Conference Series

Vol. 2 No. 1 Mei 2020

elSSN: 2686-3472

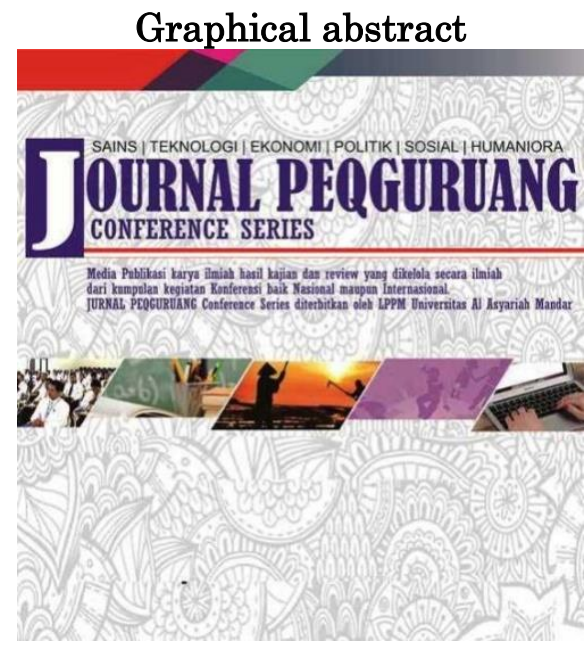

\section{SISTEM INFORMASI PENJUALAN BUKU BERBASIS WEB PADA TOKO BUKU MONSTER BOOK KABUPATEN MAMUJU}

\author{
${ }^{1}$ Nilmawati ${ }^{*},{ }^{1}$ Muhammad Assidiq, ${ }^{1}$ Syarli \\ ${ }^{1}$ Sistem Informasi, Universitas Al syariah Mandar \\ Corresponding author \\ Nilmawatii@gmail.com
}

\begin{abstract}
E-Commerce is the activity of buying and selling goods / services or transmission of funds/data through electronic networks, especially the internet. With the development of information technology and software, this has made conventional transactions possible electronically. The purpose of this research is to design a websitebased sales information system related to the lack of support that can support communication between visitors with the monster book shop. In this system the admin enters the available book titles along with the price processed in the database and the results are output in the form of book information and prices available on the website while the visitor places an order on the website provided then the admin will receive how many book orders have been sent by visitors who will buy the book are available next admin has access to the website provided to confirm visitors whether the order is accepted or not. The results of this study are an application of Web-Based Book Sales Information System at Monster Book Bookstore Mamuju using the php and html programming languages.
\end{abstract}

Keywords: Book, E-commerce, Information Systems

\begin{abstract}
Abstrak
E-Commerce adalah Kegiatan jual beli barang/jasa atau transmisi dana/data melalui jaringan elektronik, terutama internet. Dengan perkembangan teknologi informasi dan software, hal ini membuat transaksi konvensional menjadi mungkin untuk dilakukan secara elektronik. Adapun tujuan dari dari penelitian ini adalah merancang system informasi penjualan berbasis website terkait belum adanya penunjang yang dapat mendukung komunikasi antara pengunjung dengan pihak took monster book. Pada sistem ini admin melakukan penginputan judul buku yang tersedia beserta harga yang di proses di database dan hasilnya outputnya berupa informasi buku dan harga yang tersedia di website sedangakan pengunjung melakukan pemesanan di website yang telah disediakan kemudian admin akan menerima berapa jumlah pesanan buku yang telah dikirim oleh pengunjung yang akan membeli buku yang tersedia selanjtnya admin memiliki akses masuk di situs web yang disediakan untuk memberi konfirmasi kepada pengunjung apakah pemesanan diterima atau tidak. Hasil penelitian ini adalah sebuah aplikasi Sistem Informasi Penjualan Buku Berbasis Web Pada Toko Buku Monster Book Mamuju menggunakan bahasa pemrograman php dan html.
\end{abstract}

Kata Kunci: Buku, E-commerce, Sistem Informasi

\section{Article history}

DOI: https://dx.doi.org/10.35329/ip.v2i1.1060

Received: 19 Januari 2020 | Received in revised form: 25 Februari 2020 | Accepted: 17 April 2020 


\section{PENDAHULUAN}

Perkembangan teknologi dibidang informasi mendorong setiap instansi atau perusahaan untuk tetap mengikuti perkembangannya, terutama berkenaan dengan perkembangan teknologi informasi yang ada hubungannya dengan kegiatan perusahaan tersebut. Perkembangan teknologi informasi telah memberikan kontribusi yang cukup berarti dalam meningkatkan kegiatan usaha khususnya dalam hal pengolahan data yang memberi dukungan terhadap pengambilan keputusan-keputusan bisnis, untuk melakukan analisis terhadap data transaksi. (syarli, 2018)

Perkembangan teknologi informasi telah memberikan kontribusi yang cukup berarti dalam meningkatkan kegiatan pelayanan. Berdasarkan pada uraian diatas pemanfaatan teknologi informasi dalam suatu aktivitas bisnis merupakan hal yang cukup penting. Begitu pentingnya hampir setiap perusahaan yang serupa menggunakan sistem pelayanan bisini secara online. Toko buku Monster Book yang berada di daerah Mamuju merupakan sebuah toko yang menyediakan berbagai macam buku yang dibutuhkan oleh masyarakat. Saat ini proses penjualan dapat dilayani melalui sebuah toko yang dapat dikunjungi oleh konsumen. Konsumen harus datang langsung ke toko buku untuk dapat melihat-lihat koleksi yang ada dan selanjutnya melakukan transaksi pembelian.

Pada saat pelaksanaannya seringkali terjadi antrian yang cukup panjang karena jumlah pengunjung yang cukup ramai, sedangkan jika dilakukan pendirian cabang baru maka akan memakan biaya dan tenaga yang cukup besar. Selain itu jangkauan pasar yang dicapai hanya terbatas pada daerah sekitar toko tersebut, sehingga hasil atau keuntungan yang dicapai tidak terlalu besar. Salah satu solusi yang cukup menjanjikan adalah pembuatan website $e^{-}$ commerce toko buku online. Agar memudahkan konsumen untuk membeli buku tanpa harus mengantri, dan memasan buku secara mudah dan melakukan pembayaran tanpa harus datang ke toko buku Monster Book. Berdasarkan uraian diatas, maka diperlukan solusi tepat yang dapat menjawab permasalahan yang ada sehingga selain memberikan keuntungan bagi toko buku tersebut juga memberikan kemudahan bagi pembeli. Oleh sebab itu dalam proposal ini diambil judul "Sistem Informasi Penjualan Buku Berbasis Web Pada Toko Buku Monster Book Mamuju”.

\section{TINJAUAN PUSTAKA}

\subsection{Sistem Informasi}

Sistem informasi merupakan kombinasi teratur dari orang-orang, perangkat keras, perangkat lunak, jaringan komunikasi, dan sumber daya yang mengumpulkan, mengubah, dan menyebarkan informasi dalam sebuah organisasi.
Selain itu sistem informasi adalah kombinasi atau gabungan dari orang-orang, perangkat lunak (hardware), software, dan sumber daya data yang mampu mengumpulkan, mengolah, mengubah dan menyebarkan informasi dalam sebuah organisasi. (Yakub, 2012)

\subsection{E-commerce}

E-commerce (perdagangan elektronik adalah kegiatan jual beli barang/jasa atau transmisi dana/data melalui jaringanlektronik terutama Website digunakan sebagai pengganti toko offline

\subsection{Website}

Website adalah lokasi di internet yang menyajikan kumpulan informasi sehubungan dengan profil pemilik situs. Website adalah suatu halaman yang memuat situs-situs web page yang berada di internet yang berfungsi sebagai media penyampaian informasi, komunikasi, atau transaksi.

\subsection{Buku}

Buku adalah kumpulan kertas atau bahan lainnya yang dijilid menjadi satu pada salah satu ujungnya dan berisi tulisan, gambar, atau tempelan. Setiap sisi dari sebuah lembaran kertas pada buku disebut sebuah halaman. Seiring dengan perkembangan dalam bidang dunia informatika, kini dikenal pula istilah e-book atau buku-e (buku elektronik), yang mengandalkan perangkat seperti komputer meja, komputer jinjing, komputer tablet, telepon seluler dan lainnya, serta menggunakan perangkat lunak tertentu untuk membacanya.

\subsection{PHP}

PHP singkatan dari Hypertext Preprocessor yang digunakan sebagai bahasa script server-side dalam pengembangan web yang disisipkan dalam dokumen HTML. PHP adalah suatu bahasa pemakai secara logik. $E R \_M$ didasarkan pada suatu presepsi bahwa real word terdiri atas obyek-obyek dasar yang mempunyai hubungan/kerelasian antar obyek-obyek dasar tersebut.

\section{6. $M y S Q L$}

$M y S Q L$ dikenal sebagai database server terutama semenjak internet menjadi populer. Software ini banyak digunakan dalam berbagai website. Yang menarik, MySQL tergolong sebagai open source dan sangat handal sehingga menjadi pilihan dalam mengelola data di berbagai organisasi. Selain itu, $M y S Q L$ dapat berjalan pada beberapa platform, dari Windows sampai ke Linux.

\section{7. $H T M L$}

HTML adalah versi yang sederhana dari SGML (Standardized Generalized Markup Language), yaitu bahasa untuk pertukaran data. Kode HTML ditulis dengan mode ASCII. Format ASCII sering disebut teks, yang bisa dibuat dengan perangkat lunak pengolah kata biasa. Hal ini cukup menguntungkan karena bisa dibaca dan ditulis oleh berbagai platform seperti IBM, Mac, Unix PHP (officially "PHP: Hypertext Preprocessor") is a serverside HTML- 
embedded scripting language." PHP (secara resmi "PHP: Hypertext Preprocessor") menurut Farid (2001) adalah sebuah bahasa skrip yang diselipkan pada $H T M L$ yang bekerja di sisi server.

\subsection{Kajian Pustaka}

Pada penelitian yang dilakukan oleh Tri Utami, dkk (2014) yang berjudul Pembangunan Sistem Informasi Penjualan Obat Pada Apotek Punung di uraikan bahwa tujuan dari penelitian ini adalah menghasilkan sistem informasi penjualan obat sebagai salah satu usaha meningkatkan efektifitas dalam memasukkan data obat dan mencari data obat sehingga dapat mempermudah dalam transaksi penjualan.

Pada penelitian yang dilakukan oleh Fendi Nurcahyono (2012) yang berjudul dalam penelitiannya Pembangunan Aplikasi Penjualan Dan Stok Barang Pada Toko Nuansa Elektronik Pacitan Pada Toko Nuansa Elektronik Pacitan di uraikan bahwa pencatatan dan pengolahan data barang, jumlah dan harga barang, data para supplier, serta data transaksi penjualan masih dilakukan dengan menggunakan tulisan tangan. Kesulitan dalam mencatat dan menghitung banyaknya jenis barang, jumlah barang, maupun besarnya jumlah harga, mengakibatkan data yang diperoleh menjadi kurang akurat. Untuk meningkatkan keakuratan data, diperlukan pembangunan sistem informasi penjualan barang yang terkomputerisasi. Aplikasi penjualan barang ini dibuat dengan menggunakan software $P H P$ sebagai pembuat interface utama dan $M y S Q L$ sebagai basis datanya.

Pada penelitian yang dilakukan oleh Rice Novita1, dkk (2015) yang berjudul Sistem Informasi Penjualan Pupuk Berbasis E-Commerce di uraikan bahwa Kebutuhan Pupuk dalam bidang pertanian sangatlah penting. Untuk membantu kesuburan tanah dan tanaman sehingga mendapatkan hasil yang bagus. PT. Pertani (Persero) merupakan perusahaan yang bergerak dibidang pendistribsian pupuk cabang Riau. Di PT.Pertani (Pesero) cabang Riau ini, rangkaian proses penjadwalan pengiriman pupuk yang dimulai dari pembuatan booking order, penjadwalan sampai proses pengiriman semuanya masih dilakukan dengan manual. Penelitian ini akan merancang sebuah Sistem Informasi Penjualan Pupuk di PT. Pertani (Persero) cabang Riau yang akan mengurangi kesalahan pendokumentasian.

Dari beberapa penelitian di atas yang pernah dilakukan, dalam penelitian ini penulis akan merancang sistem dan membuat Sistem Informasi penjualan buku pada toko monster book berbasis website dengan menggunakan bahasa pemrograman PHP dan database MySQL. Sistem akan melibatkan admin dan pimpinan dengan aksesibilitas yang berbeda-beda. Fungsionalitas sistem akan membantu pengelolaan buku pada toko monster book data penjualan dan stok buku

\section{METODE PENELITIAN}

\subsection{Alat Penelitian}

a. Perangkat lunak (Software)

Adapun perangkat lunak yang di butuhkan dalam membuat sistem informasi penjualan buku yaitu database yang akan digunakan $M y S Q L$, menggunakan bahasa pemrograman $P H P, X A M P P$ sebagai server local, menggunakan Sistem Operasi windows 10.

\section{b. Perangkat Keras (Hardware)}

Adapun perangkat keras yang di butuhkan dalam membuat sistem informasi penjualan buku yaitu Laptop dengan spefikasi minimum intel celeron, Media penyimpanan hardisk $500 \mathrm{~Gb}$, $R A M 2.00 \mathrm{~Gb}$.

\subsection{Bahan Penelitian}

Data yang di butuhkan dalam penelitian ini yaitu data buku yang terdapat pada transaksi dan pegawai pada toko monster book tersebut.

3.3. Tekhnik Pengumpulan Data

Prosedur penelitian diawali dengan melakukan identifikasi masalah, kemudian mengumpulkan bahan berupa data, observasi, wawancara dan tinjauan pustaka. (Assiddiq, M. 2016)

3.4. Kerangka Sistem

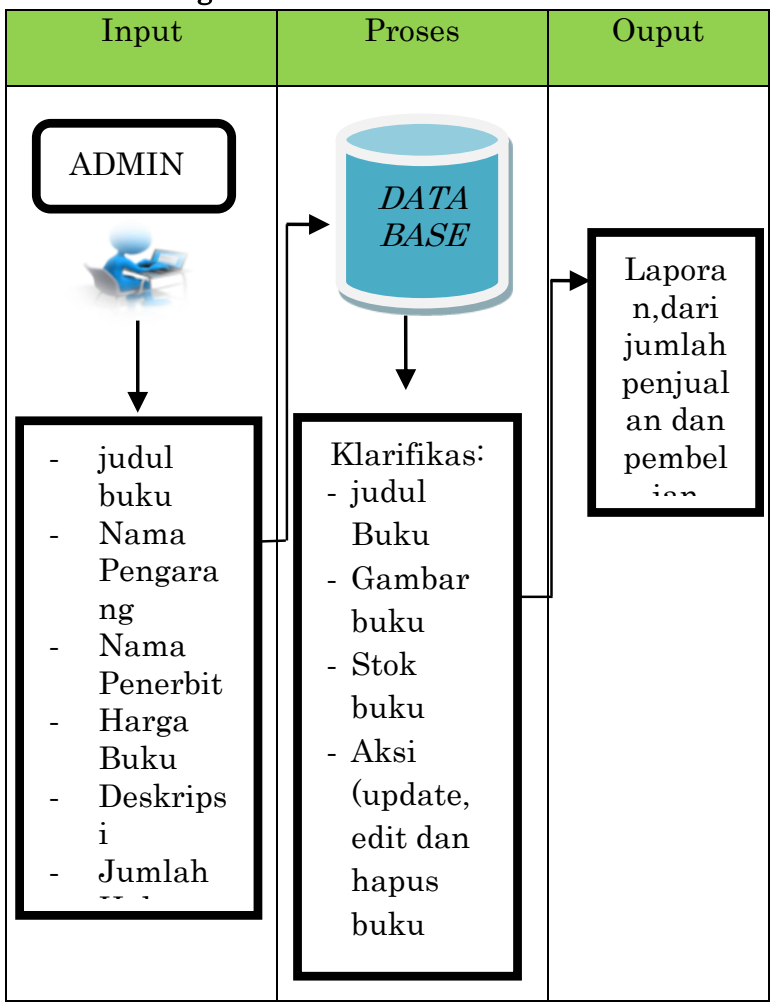

Gambar 1. Kerangka Sistem

Pada kerangka sistem diatas menjelaskan secara bertahap tentang tahapan yang dilakukan oleh sistem informasi penjualan buku mulai dari input, proses dan output. Berdasarkan gambar 3.2. dapat dijelaskan beberapa tahapan sebagai berikut:

1. Admin melakukan penginputan judul buku 
yang tersedia beserta harga yang di proses di database dan hasilnya outputnya berupa informasi buku dan harga yang tersedia di website.

2. Pengunjung melakukan pemesanan di website yang telah disediakan.

3. Admin akan menerima berapa jumlah pesanan buku yang telah dikirim oleh pengunjung yang akan membeli buku yang tersedia. admin memiliki akses masuk di situs web yang disediakan untuk memberi konfirmasi kepada pengunjung apakah pemesanan diterima atau tidak.

\subsection{Analisa dan Perancangan Sistem}

Berikut gambaran sistem informasi penjualan buku yang sedang berjalan dan yang sedang diusulkan pada toko buku monster book kabupaten Mamuju

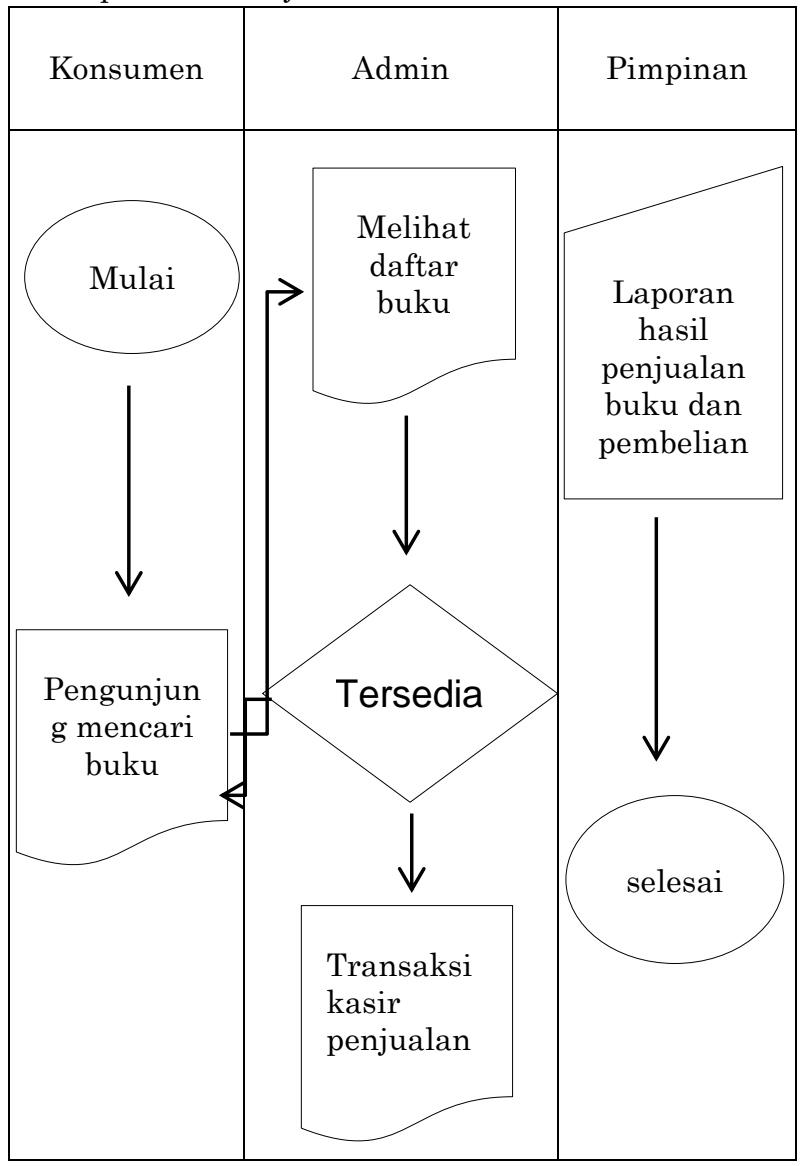

Gambar 2. Diagran Alir Yang Sedang Berjalan

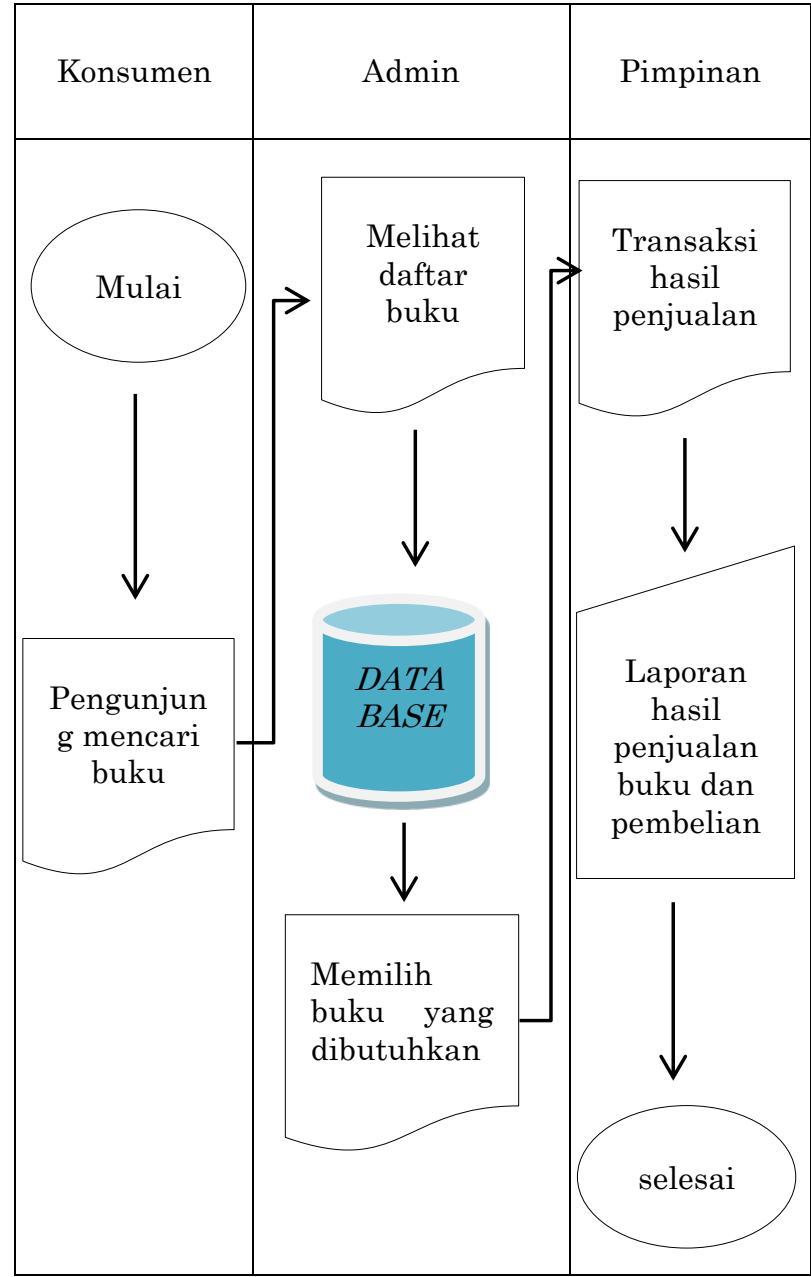

Gambar 3. Diagram Sistem yang diusulkan

\section{HASIL DAN PEMBAHASAN}

\subsection{Hasil Penelitian}

Hasil penelitian ini adalah sebuah aplikasi Sistem Informasi Penjualan Buku Berbasis Web Pada Toko Buku Monster Book Mamuju "menggunakan bahasa pemrograman php dan html.

Pada Sistem Informasi Penjualan Buku Berbasis Web Pada Toko Buku Monster Book Mamuju ini menyediakan fitur bagi pengguna di bagian awal tampilan yakni beranda menampilkan informasi berupa daftar produk yang dijual, menu Profil menampilkan informasi dari pengguna yang telah login, menu semua produk menampilkan semua produk yang dijual, menu keranjang menampilkan informasi berupa daftar produk yang akan dibeli pada sistem. 


\subsection{User Interface Program \\ 1. Form Login}

\section{Silahkan Login}

\section{Username}

\section{enail}

Password

\section{Password}

Masuk belum punya akun? Daftar

\section{Gambar 4. Form Login}

Form Login berfungsi sebagai form untuk mengakses layanan pada sistem berdasarkan level pengguna yang terdiri dari username/akun pengguna dan password untuk medapatkan hak akses. Untuk bisa masuk kedalam sistem maka pengguna baru perlu melakukan registrasi terlebih dahulu.

\section{Form Registrasi}

\section{Silahkan mengisi form pendaftaran}

Nama
Nama Lengkap anda
Alamat Email
email anda
Password
password
Simpan Actiate Wif

Gambar 5. Form Registrasi

Form Registrasi berfungsi sebagai form untuk mendaftarkan diri bagi pengguna baru yang akan melakukan transaksi pada toko buku monster book.

\section{Form Admin}

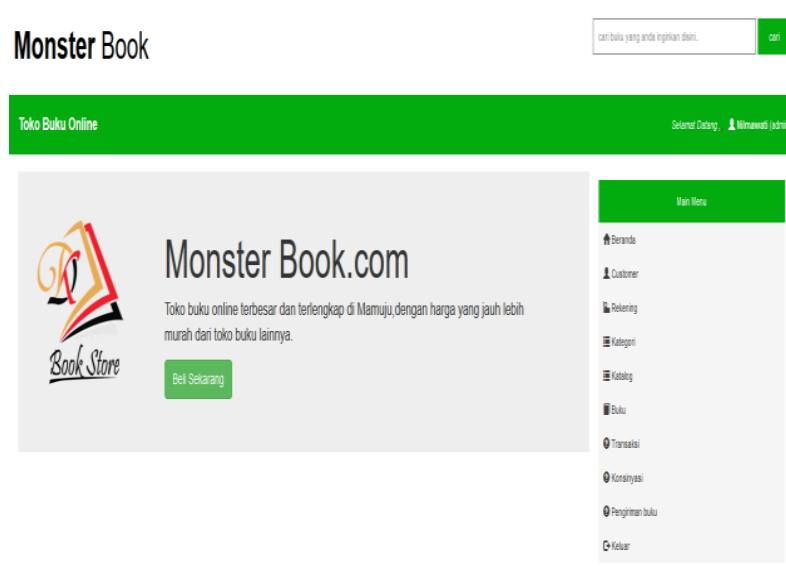

Gambar 6. Form Admin

Form Admin berfungsi sebagai form untuk pengguna serta admin untuk mengelolah semua data user dan pembeli, data buku, transaksi dan konfirmasi pembeli

\section{Form Konfirmasi Pembayaran}

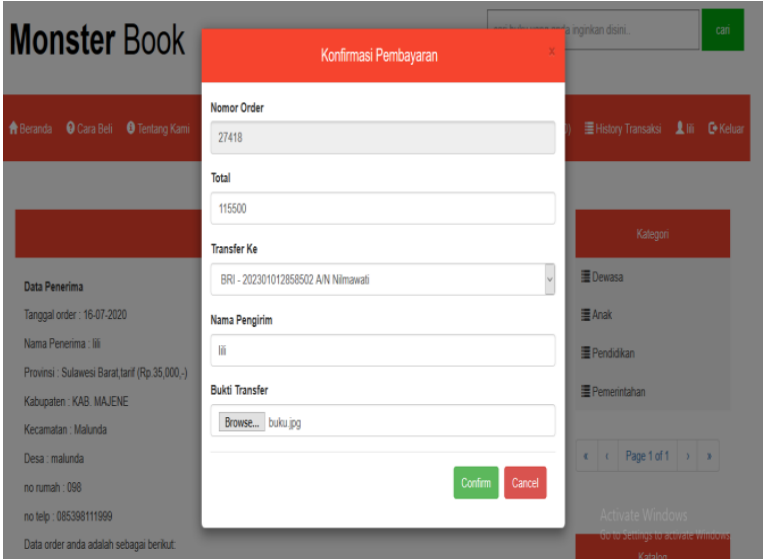

Gambar 7. Form Registrasi

Form konfirmasi pembayaran adalah form yang berisi tentang proses validasi pembelian buku dengan menampilkan hasil transaksi dari yang dilakukan oleh user/konsumen.

\section{Form Laporan data Transaksi}

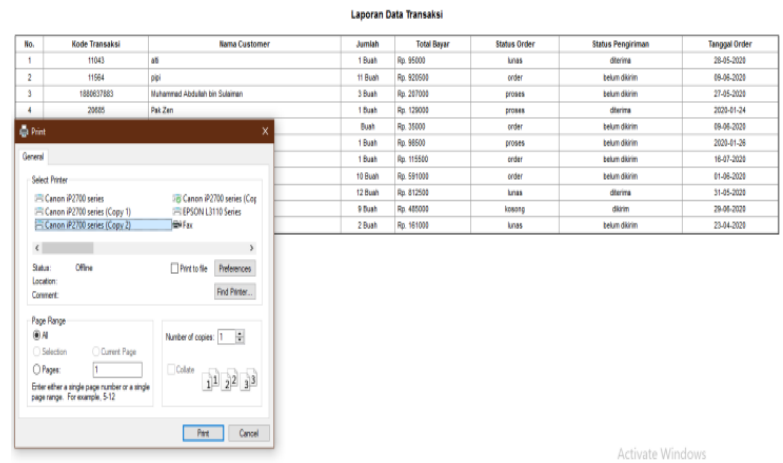

Gambar 8. Form Registrasi 
Form laporan data transaksi adalah form yang berisi semua hasil laporan/output penjualan buku yang ada dalam sistem penjualan yang di format dalam bentuk pdf.

\section{KESIMPULAN DAN SARAN}

\subsection{Kesimpulan}

Kesimpulan dari skripsi yang berjudul: "Sistem Informasi Penjualan Buku pada toko monster book Mamuju" adalah dengan adanya Sistem Penjualan Buku ini dapat membantu dalam mengelola data penjualan dan memberi kemudahan pada penjual dan pembeli dalam melakukan transaksi pembelian buku pada toko Moster book Mamuju.

5.2. Saran

Dalam pembuatan Sistem Informasi Penjualan Buku pada Toko Monster Book Kabupaten Mamuju ini masih banyak hal yang dapat dikembangkan seperti Sistem informasi Produk penjualan yang sudah dibangun bisa dikembangkan ke arah android sehingga bias mempercepat proses ketetapan dalam melakukan transaksi dengan pilihan metode pembayaran yang bias dipilih yaitu Transfer atau COD, Pemilihan jasa pengiriman barang yaitu JNE Express, TIKI, J\&T, Sicepat, Kantor pos. Demikian saran yang dapat penulis berikan, semoga saran tersebut bisa dijadikan sebagai bahan masukan untuk penelitian berikutnya Pada sistem penjualan elektronik.

\section{DAFTAR PUSTAKA}

Syarli, S., Tamin, R., \& Qashlim, A. 2018. Perancangan Business Intelligence System Pada Gudang Farmasi Dinas Kesehatan Kabupaten Mamasa. Jurnal Keteknikan dan Sains (JUTEKS), 1 (1), 7-14.

Tri utami, Bambang Eka Purnama, Sukadi 2014, Pembangunan sistem informasi penjualan obat pada Apotek Punung, (Meliputi: Input data dan laporan).

Fendi Nurcahyono. 2012. Pembangunan aplikasi penjualan dan stok Barang dengan PHP, MySQL. Pacitan: Toko Nuansa Elektronik.

Rice novita, Novita sari 2014, Sistem Informasi Penjualan pupuk berbasis E-commerse. Riau: PT. Petani (Persero).

Yakub 2012. Analisis dan Dasar Sistem Informasi Manajemen. Pendekatan Terstruktur. Yogyakarta

Rice novita, Novita sari 2014, Sistem Informasi Penjualan pupuk berbasis E-commerse. Riau:PT. Petani(Persero).

Tri Utami, Bambang Eka Purnama, Sukadi 2014 , Analisis dan Desain Sistem Informasi. Edisi kedua cetakan kedua. Yogyakarta: Penerbit Andi.

Assiddiq, M. (2016). Sistem Informasi Akuntansi Media Mandar Malaqbiq. Jurnal Ilmiah Ilmu
Komputer Fakultas Ilmu Komputer Universitas Al Asyariah Mandar, 2(1), 18-21. 